\title{
Premature senescence involving p53 and p16 is activated in response to constitutive MEK/MAPK mitogenic signaling
}

\author{
Athena W. Lin,, Marta Barradas, ${ }^{2}$ James C. Stone, ${ }^{3}$ Linda van Aelst, ${ }^{1}$ Manuel Serrano, ${ }^{2}$ \\ and Scott W. Lowe ${ }^{1,4}$ \\ ${ }^{1}$ Cold Spring Harbor Laboratory, Cold Spring Harbor, N ew York 11724 USA; ${ }^{2}$ Department of Immunology and Oncology, \\ Centro N acional de Biotecnologá, Cantoblanco, Madrid E-28049, Spain; ${ }^{3}$ Department of Biochemistry, University of Alberta, \\ Edmonton, Alberta T6G 2H7, Canada
}

\begin{abstract}
Oncogenic Ras transforms immortal rodent cells to a tumorigenic state, in part, by constitutively transmitting mitogenic signals through the mitogen-activated protein kinase (MAPK) cascade. In primary cells, Ras is initially mitogenic but eventually induces premature senescence involving the p53 and p16 ${ }^{1 \mathrm{NK} 4 \mathrm{a}}$ tumor suppressors. Constitutive activation of MEK (a component of the MAPK cascade) induces both p53 and p16, and is required for Ras-induced senescence of normal human fibroblasts. Furthermore, activated MEK permanently arrests primary murine fibroblasts but forces uncontrolled mitogenesis and transformation in cells lacking either p53 or IN K4a. The precisely opposite response of normal and immortalized cells to constitutive activation of the MAPK cascade implies that premature senescence acts as a fail-safe mechanism to limit the transforming potential of excessive Ras mitogenic signaling. Consequently, constitutive MAPK signaling activates $\mathrm{p} 53$ and $\mathrm{p} 16$ as tumor suppressors.
\end{abstract}

[Key Words: MAPK signaling; premature senescence; MEK; tumor suppression; p53; p16]

Received June 8, 1998; revised version accepted August 9, 1998.

Cancer arises through the accumulation of genetic changes that each enhances the growth or survival of developing tumor cells (Fearon and Vogelstein 1990). Perhaps the simplest experimental model of this multistep process involves transformation of primary cultures by ras oncogenes (Weinberg 1989; Ruley 1990). Oncogenic Ras transforms most immortal rodent cells to a tumorigenic state, whereas transformation of primary cells requires either a cooperating oncogene (e.g., E1A) or the inactivation of tumor suppressors such p53 or INK4a (Gallimore et al. 1986; Tanaka et al. 1994; Serrano et al. 1996). Importantly, these transforming interactions have been validated in animal models and, in several instances, the genetic changes that cooperate with ras in primary cells are comutated with ras in spontaneous tumors (Fearon and Vogelstein 1990; Burns et al. 1991; Kemp et al. 1993; Linardopoulos et al. 1995; Chin et al. 1997).

Despite the widespread use of oncogene cooperation assays to model genetic interactions during tumorigenesis, a biological explanation for this phenomenon is only now emerging. Primary rodent and human cells un-

${ }^{4}$ Corresponding author.

E-MAIL lowe@cshl.org FAX (516) 367-8454. dergo a limited number of cell doublings in culture and then undergo a process of cellular senescence (Hayflick 1965). When expressed al one, most oncogenes that cooperate with ras in transformation extend cellular life span in human cells, and facilitate the establishment of primary rodent cells into immortal cell lines (Ruley 1990). This observation suggested that oncogenic Ras requires 'immortalizing' changes to promote oncogenic transformation; these could occur spontaneously in immortal cell lines or be provided by a cooperating oncogene (for review, see Weinberg 1997). At the same time, other studies suggested that normal cells actively resist transformation by Ras (Franza et al. 1986; Hirakawa and Ruley 1988), implying that cooperating oncogenes interfere with natural anti-oncogenic defenses.

We demonstrated recently that prolonged expression of oncogenic Ras induces a permanent cell-cycle arrest in primary human and rodent fibroblasts that is phenotypically indi stinguishable from cellular senescence (Serrano et al. 1997). Consequently, these studies explain the requirement for immortalizing changes in ras transformation assays, and identify a mechanism whereby normal cel Is actively counter ras' transforming potential. For example, because immortal rodent cell lines have al ready lost aspects of the senescence program, they are readily 
transformed by oncogenic Ras alone. Similarly, immortalizing oncogenes disrupt the senescence program retained in primary cells; hence, such changes interfere with the ability of oncogenic Ras to provoke senescence. In either case, cells escape normal growth controls that actively limit transformation by Ras. Consequently, premature senescence may function as a bona fide mechanism of tumor suppression (Serrano et al. 1997; for review, see Weinberg 1997).

Consistent with this view, p53 and p16 IN K4a appear critical for premature senescence induced by oncogenic Ras (Serrano et al. 1997). Both p53 and INK4a are mutated at high frequency in many tumor types, implying that their action is central to tumor development. N evertheless, the precise circumstances in which either is engaged to function as tumor suppressors remain poorly understood. p53 can promote cell-cycle arrest or apoptosis in response to a variety of cellular stresses, including DN A damage and hypoxia (Kastan 1993; Graeber et al. 1996). In both settings, cells acquiring p53 mutations have a selective advantage over their p53-normal counterparts. p16 increases gradually as cells proceed towards senescence (Alcorta et al. 1996; Zindy et al. 1997). Consequently, loss of p16 might uncouple the cell-cycle machinery from a cell-doubling clock, allowing developing tumor cells to proliferate beyond their normal life span. The fact that oncogenic Ras activates p53 and p16 provides an additional explanation for their action as tumor suppressors: p53 and p16 act in a compensatory mechanism that suppresses Ras-induced transformation. Hence, cells acquiring p53 and I NK4a mutations would tolerate ras mutations occurring early in tumor development (Serrano et al. 1996).

In immortal rodent lines, transformation by oncogenic Ras involves its ability to bind and activate a series of effector proteins, including Raf-1, phosphoinositide 3-OH kinase [PI (3)K], and Ral.GDS (Van Aelst et al. 1993; Rodriguez-Viciana et al. 1994; Spaargaren and Bischoff 1994). Each of these proteins, in turn, activates distinct downstream targets, thereby producing different aspects of the transformed phenotype (for review, see Katz and McCormick 1997). For example, the Ras-Raf interaction initiates the mitogen-activated protein kinase (MAPK) cascade, which involves the sequential activation of a series of protein kinases that transmit mitogenic signals to nucl ear transcri ption factors (Chen et al. 1992; Gilleet al. 1995). These kinases include Raf-1, the MEKs (MEK1 and MEK2), and the MAPKs (ERK1 and ERK2). In contrast, the ability of Ras to activate PI(3)K promotes membrane ruffling (Joneson et al. 1996; Rodriguez-Viciana et al. 1997), perhaps through Rac and Rho (for review, see Van Aelst and D'Souza-Schorey 1997), and may also suppress apoptosis through activation of Akt/PKB (for review, see Downward 1998). Finally, the Ral.GDS proteins act as exchange factors that can activate the Ral family of small GTPases (Spaargaren and Bischoff 1994) which, in turn, can regulate phosphol ipase D (jiang et al. 1995). Although each of these effector pathways contributes to the transforming activity of Ras in immortal rodent fi broblasts (Khosravi-Far et al. 1995, 1996; White et al. 1995; Urano et al. 1996; Rodriguez-Viciana et al. 1997), activation of the MAPK cascade is clearly sufficient (Cowley et al. 1994; M ansour et al. 1994; Bottorff et al. 1995; Stang et al. 1997).

Almost all of the studies examining Ras signaling in mammalian systems have utilized immortal or tumorderived lines harboring unknown genetic alterations. Because premature senescence induced by Ras is restricted largely to nonimmortal cells (Serrano et al. 1997), Ras might signal premature senescence through an unidentified pathway lost during the immortalization process. Alternatively, Ras could promote premature senescence through a known effector pathway or by activating a combination of effector pathways. In the current study, we identified the effector pathway responsible for Rasinduced senescence. We find that Ras induces senescence in normal cells through the primary mechanism whereby it forces uncontrolled proliferation and transformation in immortal cell lines. These results have important implications for our understanding of oncogene cooperation, tumor suppression, and the regulation of cellular senescence.

\section{Results}

Oncogenic Ras is initially mitogenic in normal diploid human fibroblasts

Microinjection of oncogenic ras into human diploid fibroblasts induces S-phase entry (Lumpkin et al. 1986). On the other hand, retroviral transduction of oncogenic ras into human fibroblasts provokes permanent cellcycle arrest (Serrano et al. 1997). These observations raise the possibility that the initial effect of Ras is forced proliferation and, only later, cell-cycle arrest. Therefore, the immedi ate and long-term consequences of oncogenic Ras expression were examined in the same population of normal diploid human IMR90 fibroblasts. In this and subsequent experiments, oncogenic ras (H-RasV12) was introduced into whole-cell populations using high-titer retroviral vectors coexpressing a selectabl e marker. After a brief selection to el iminate uninfected cells, cells were plated for all assays described bel ow (desi gnated day -1 ). Using this protocol, the percentage of transduced cells ranged between $70 \%$ and $90 \%$ as estimated in parallel infection with viruses expressing a lacZ reporter (data not shown).

To examine the proliferation properties of Ras-expressing populations, $\left[{ }^{3} \mathrm{H}\right]$ thymidine and $\mathrm{BrdU}$ incorporation were measured shortly after ras transduction (48$72 \mathrm{hr}$ postinfection) in the presence and absence of serum. In normal growth conditions ( $10 \%$ serum), vector and Ras-expressing cells incorporated similar amounts of $\left[{ }^{3} \mathrm{H}\right]$ thymidine (Fig. 1A). As expected, transfer of vectorcontaining cells to low serum for $24 \mathrm{hr}$ resulted in a marked reduction in $\left[{ }^{3} \mathrm{H}\right]$ thymidine incorporation. By contrast, Ras-expressing cells continued to incorporate high levels of $\left[{ }^{3} \mathrm{H}\right]$ thymidine even after serum depletion. Similarly, Ras-expressing cells placed in low serum incorporatated twice as much BrdU as cells containing an 
Figure 1. Oncogenic Ras is initially mitogenic in primary fibroblasts. $(\mathrm{A})\left[{ }^{3} \mathrm{H}\right]$ thymidine incorporation assay using IM R90 cell populations containing empty vector $(V)$ or H-RasV12 (R). Twenty-four hours postinfection, $2 \times 1^{4}$ of the indicated cells were plated and grown in medium containing $10 \%$ FBS or $0.5 \%$ FBS for $24 \mathrm{hr}$ followed by $a^{3} \mathrm{H}$ ]thymidine pulse. Values were normalized to those obtained from control populations in 10\% serum; the average and standard deviation of three measures are shown. (B) Cell-cycle analysis of IMR90 cell populations containing empty vector (V) or H-RasV12 (R) in low-serum conditions. Twenty-four hours postinfection, cells were transferred to $0.5 \%$ FBS-contain-

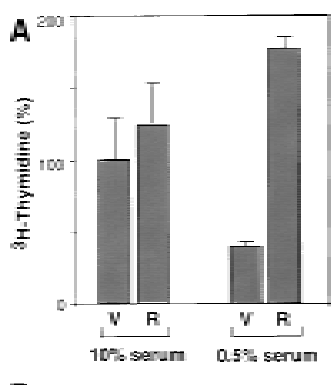

B

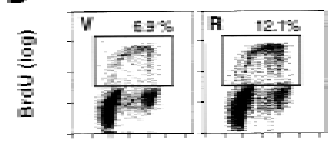

C

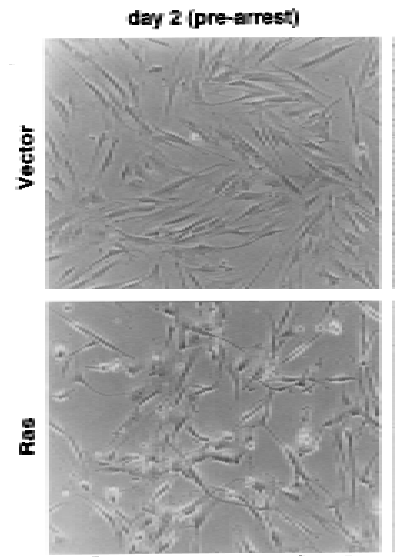

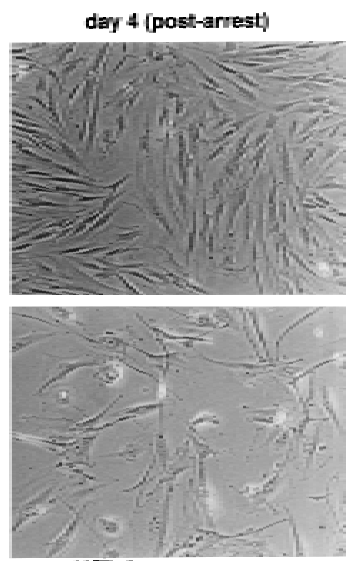

ing medium, $24 \mathrm{hr}$ later, the cells werepulsed with BrdU for $4 \mathrm{hr}$; and analyzed for BrdU incorporation and DN A content by two-color flow cytometry (see M aterials and M ethods). The box represents cells incorporating BrdU (S-phase); the percentage of BrdU positive cells are indicated. (C) Representative photomicrographs of IM R90 cells transduced with empty vector or a H-RasV12-expressing construct. Cells were transduced with retroviruses containing either empty vector or H-RasV12; the photomicrographs were taken at day 2 postselection (prearrest) and day 4 postsel ection (postarrest) according to the time scheme described in M aterials and $M$ ethods.

empty vector (Fig. 1B). Initially, proliferation in the presence of oncogenic Ras was accompanied by morphological changes characteristic of constitutive Ras activity in immortal cells, becoming small and refractile with thin cytoplasmic projections (Fig. 1C). Only later do Ras-expressing cells acquire the characteristic senescent morphology (Fig. 1C; see al so Serrano et al . 1997). Therefore, the immediate consequences of oncogenic Ras expression are forced proliferation, implying that cell-cycle arrest is an antiproliferative cellular response.

\section{Ras effectors and cell-cycle arrest}

As a first step in identifying the Ras-si gnaling pathway(s) required for premature senescence, we exploited a series of Ras 'effector loop' mutants that interact preferentially with specific Ras effector proteins (White et al. 1995; Joneson et al. 1996). For example, H-RasV12/S35 binds preferentially to Raf-1 and activates MAPK but has no effect on membrane ruffling (White et al. 1995). In contrast, H-RasV12/C40 associates with $\mathrm{PI}(3) \mathrm{K}$ and promotes membrane ruffling and cell survival but does not bind Raf-1 or induce mitogenesis (Joneson et al. 1996; Rodriguez-Viciana et al. 1997). H-RasV12/G37 binds Ral.GDS but fails to bind Raf-1 or PI(3)K (White et al. 1995). IM R90 human fibroblasts were infected with retroviruses expressing individual Ras mutants, and cell proliferation was determined by assessing relative cell accumulation at various times postplating (Serrano et al. 1997).

Consistent with previous results, constitutive expression of oncogenic Ras induced cell-cycle arrest at subconfluent densities and in the presence of serum, whereas cells harboring the empty vector grew exponentially to confluence (Fig. 2A). Cell populations expressing the H-RasV12/G37 or H-RasV12/C 40 mutants failed to arrest, suggesting that neither the Ras-PI(3)K interaction nor the Ras-Ral.GDS interaction is sufficient to in-
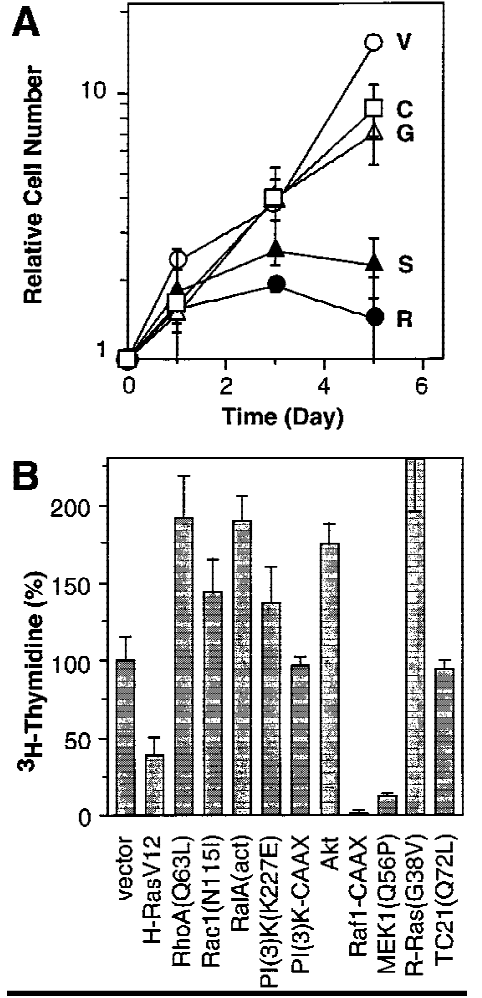

Figure 2. Effect of Ras-dependent signaling pathways on proliferation. (A) Representative growth curves corresponding to the indicated IM R90 cell populations containing empty vector

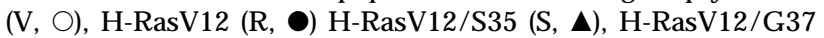
(G, $\triangle$ ), H-RasV12/C40 (C, $\square$ ). Each value was determined in triplicate and normalized to the cell number at day 0 . (B) Representative $\left[{ }^{3} \mathrm{H}\right]$ thymidine incorporation assay of IMR90 cell populations expressing various Ras-related proteins, Ras effectors or Ras downstream components (see M aterials and M ethods). The values were normalized to those obtained from cells containing a control vector; the average and standard deviation of three measures are shown. 
duce cell-cycle arrest. In contrast, cells expressing $\mathrm{H}-$ RasV12/S35 grew slowly, at rates similar to cells expressing H-RasV12 (Fig. 2A). Of note, each Ras mutant was expressed at levels equal to (or greater than) $\mathrm{H}-$ RasV12, ranging from a 5- to 10-fold increase over endogenous Ras expression (data not shown). Therefore, the differential effects of each mutant were not caused by variations in Ras expression but, more likely, by their ability to interact with distinct effector proteins. These results correlate the Ras-Raf interaction with Ras-induced cell-cycle arrest in normal diploid human fibroblasts.

Because the Ras effector loop mutants were characterized in immortal cell lines, it is formally possible that they possess different activities in primary cells. As an alternative approach, selected Ras effectors (Raf-1, $\mathrm{PI}(3) \mathrm{K}$ ), downstream components (Rac, Akt, RalA, RhoA, MEK 1) (see Introduction), or Ras-related proteins (R-Ras, TC21) were tested for their ability to cause growth arrest by retroviral transduction into IMR90 human fibroblasts. Of note, R-Ras is highly homologous to H-Ras, and interacts with $\mathrm{PI}(3) \mathrm{K}$ and activates the $\mathrm{PI}(3) \mathrm{K} / \mathrm{Akt}$ pathway but not the MAPK pathway in vivo (Marte et al. 1997). TC21 is more closely related to H-Ras than any other known member of the Ras superfamily but does not activate Raf (Graham et al. 1996). Consequently, HRas, R-Ras, and TC21 stimulate cell growth and transformation via distinct signaling pathways. After selection for virus-infected populations, cells were plated at subconfluent densities and pulsed with $\left[{ }^{3} \mathrm{H}\right]$ thymidine in the presence of $10 \%$ serum. Among the Ras effectors and downstream components examined, some enhanced proliferation, whereas others had little effect (Fig. 2B). Only constitutively active Raf- 1 and MEK-components of the MAPK cascade-inhibited proliferation (Fig. 2B; see also Zhu et al. 1998). N either R-Ras nor TC21 produced cell-cycle arrest. Therefore, both the Ras mutant and effector analysis are consistent: Ras-induced arrest in normal diploid human fibroblasts involves activation of the MAPK cascade.

Activation of the MEK/MAPK cascade induces p53, p16, and premature senescence

The MEKs are dual specificity protein kinases that, upon activation, phosphorylate the threonine and tyrosine regulatory sites of MAPKs (for review, see Marshall 1994). MEK $1^{\text {Q56P }}$ is a M EK mutant identified by virtue of its ability to enhance the transforming activity of otherwise transforming-defective Ras mutants. Substitution of glutamine to proline at codon 56 results in a gain-offunction mutant that has increased kinase activity (Bottorff et al. 1995). To better characterize MEK-induced arrest, the proliferation properties of IM R90 cell populations containing a control vector, oncogenic Ras, or MEK1 ${ }^{\mathrm{Q} 56 \mathrm{P}}$ were measured by growth curves, or by BrdUlabeling and flow cytometry (Serrano et al. 1997). Activated MEK causes arrest even more rapidly than oncogenic Ras, with cells displaying a dramatic reduction in BrdU incorporation [compare 0.6\% (MEK) and 0.3\% (Ras) to $24.5 \%$ (vector) (Fig. 3A,C)]. Likewise, M EK-expressing cells arrest primarily with $\mathrm{a}_{1}$ DNA content, al though there is a clear $\mathrm{G}_{2}$ component (Fig. 3C). Importantly, both oncogenic Ras and MEK $1^{\mathrm{Q} 56 \mathrm{P}}$ activate MAPK in human fibroblasts (Fig. 3B).

The adenovirus E1A oncogene cooperates with ras to transform primary rodent fibroblasts (Ruley 1990) and abrogates Ras-induced senescence (Serrano et al. 1997). To determine the effect of E1A on MEK-induced arrest, IM R90 cells were infected sequentially with retroviruses expressing $\mathrm{E} 1 \mathrm{~A}$, and then either $\mathrm{MEK} 1^{\mathrm{Q} 56 \mathrm{P}}$ or a control
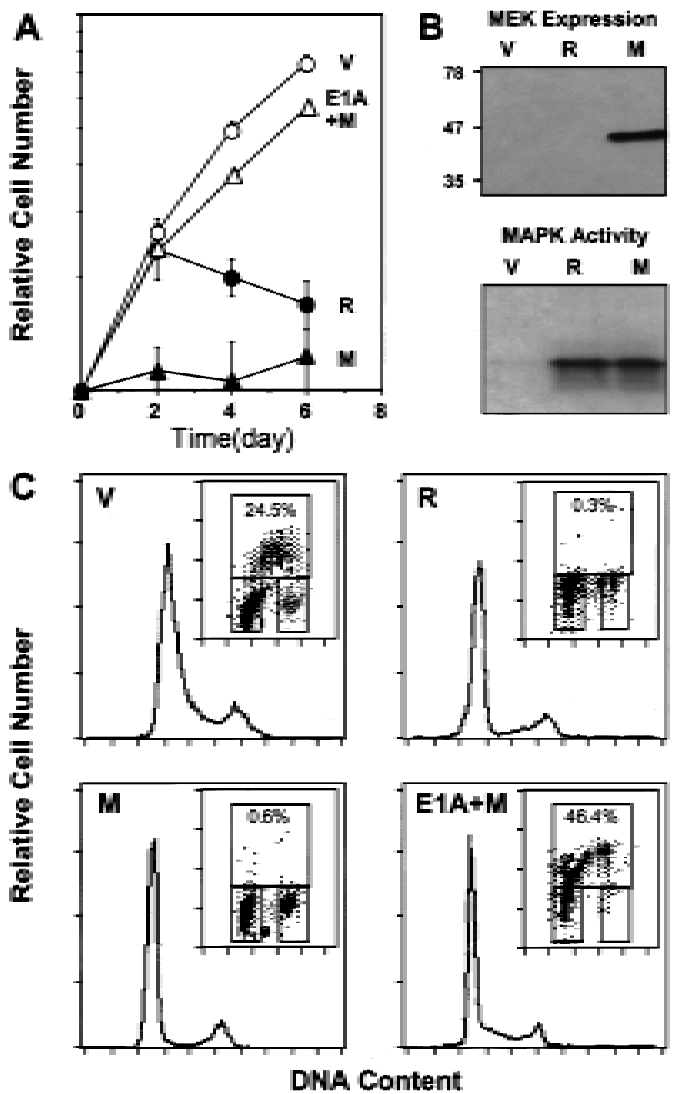

Figure 3. Activated MEK induces cell-cycle arrest in human diploid fibroblasts. (A) Representative growth curves corresponding to IM R90 cell populations transduced with empty vector $(\mathrm{V}, O), \mathrm{H}$-RasV12 (R, - $)$, MEK1 ${ }^{\mathrm{Q} 56 \mathrm{P}}(\mathrm{M}, \boldsymbol{\Delta})$ or $E 1 A+M E K 1^{Q 56 P}(E 1 A+M, \triangle)$. Each value was determined in triplicate and normal ized to the cell number at day 0 . (B) Expression of ectopic MEK $1^{\text {Q56P }}$ in retrovirally infected IMR90 cells was verified by immunoblot analysis at day 4 postselection. MAP kinase activity in cell populations at day 2 postselection was measured by immunoprecipitation of ERK2, followed by a kinase assay using $\left[\gamma^{32}{ }^{32}\right.$ PATP and myelin basic protein as substrate (see M aterials and M ethods). (C) Cell-cycle analysis of the indicated cell populations (day 6 postselection) as determined by BrdU incorporation and DN A-content analysis (see M aterials and Methods). The histogram displays the DNA profile of the indicated cell population as measured by propidium iodide. (Insets) The upper box indicates cells incorporating BrdU (S phase); the lower-left box displays $G_{0} / G_{1}$ cell population; the lower-right box indicates cells in $\mathrm{G}_{2} / \mathrm{M}$. 
vector. Cell populations coexpressing E1A and MEK $1^{\text {Q56P }}$ accumulated at rates comparable to vectorcontaining cells and incorporated high levels of BrdU, showing no signs of cell-cycle arrest (Fig. 3A,C). Consequently, as in the case of Ras-expressing cells, E1A effectively counters MEK-induced arrest and allows uncontrolled proliferation.

Cellular senescence is accompanied by a series of changes that, together, distinguish senescence from quiescence or differentiation. These changes include altered expression of cell-cycle proteins, upregulation of p53, p16, and p21, and the accumulation of senescence-associated $\beta$-galactosi dase (SA- $\beta$-gal) ( $N$ oda et al. 1994; Atadja et al. 1995; Dimri et al. 1995; Alcorta et al. 1996; Reznikoff et al. 1996). Like cells expressing oncogenic Ras, MEK1 ${ }^{\mathrm{Q56P}}$-expressing cells harbored underphosphorylated Rb and lost cyclin A expression (Fig 4). Also, MEK induced p53 (about threefol d induction), p21 (about fivefold induction), and p16 (about sixfold induction) (Fig. 4). Finally, MEK $1^{\mathrm{Q} 56 \mathrm{P}}$-expressing cells exhibited high levels of SA- $\beta$-gal activity, with a percentage of positive cells similar to that observed in Ras-expressing or late passage IMR90 cells (Fig. 5A,B). Of note, these effects require constitutive MEK activation, because cells overexpressing a wild-type MEK allele grow normally, display normal levels of p53, p21, p16, and are negative for SA- $\beta$-gal activity (data not shown).

These data indicate that the cell-cycle arrest produced

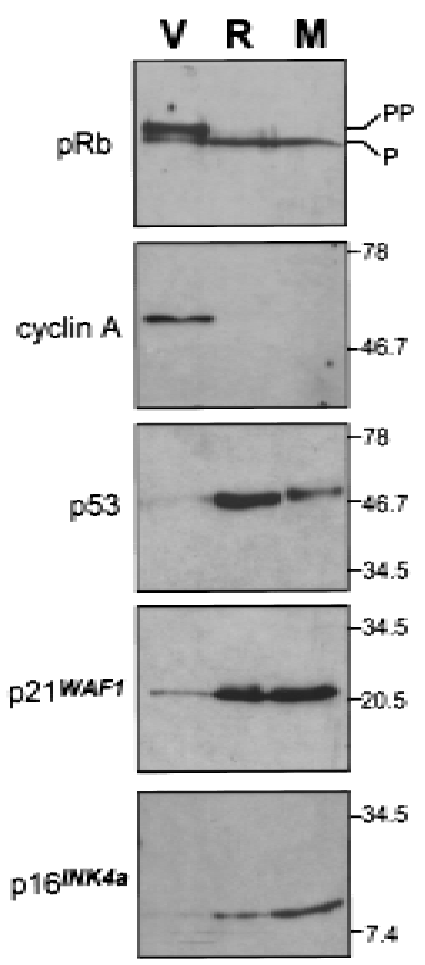

Figure 4. Activated MEK induces accumulation of p53 and p16. Immunoblots of cell-cycle regulatory proteins in Iysates from cells containing empty vector (V), H-RasV12 (R), or $\operatorname{MEK}^{\mathrm{Q} 6 \mathrm{P}}(\mathrm{M})$ at day 4 postselection.
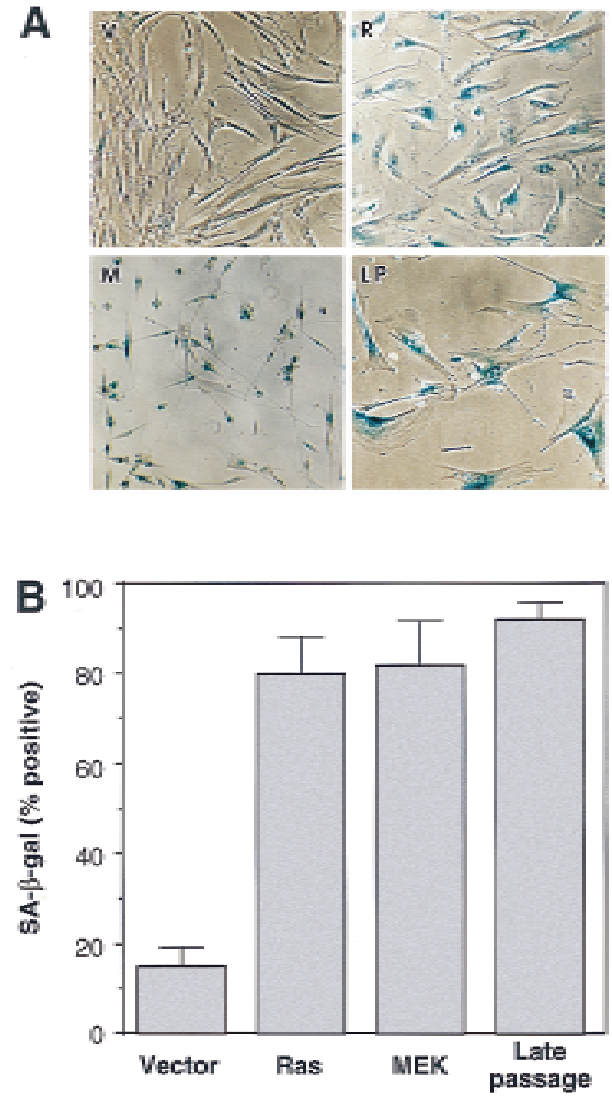

Figure 5. MEK activates premature senescence. (A) Photomicrographs of IM R90 cell populations containing an empty vector (V), H-RasV12 (R), or MEK1 ${ }^{\text {Q56P }}$ (M) stained for SA- $\beta$-gal actosidase activity (pH 6.0) at day 6 postsel ection. Late-passage IM R90 cells (LP) having undergone replicative senescence are shown for comparison. (B) Percentage of cells positive for SA- $\beta$-galactosi dase 6 days after drug selection. Cells $(\sim 200)$ from each cell population were scored; the average and standard deviation of data from at least three separate experiments are shown.

by oncogenic Ras and activated MEK is virtually identical and is characteristic of cellular senescence. Indeed, the only difference we observed between these populati ons is their morphology: Whereas Ras-arrested cells be came large and flat, MEK-arrested cells were small and refractile (Fig. 5A). N everthel ess, MEK-expressing cells remain arrested in a metabolically active state for as I ong as we have observed them ( $>2$ weeks). Because Rho family members mediate changes in cell morphology in other settings (for review, see Van Aelst and D'SouzaSchorey 1997), they may contribute to the morphological changes observed in Ras-arrested cells. N evertheless, cell morphology has been dissociated from senescence in other settings (Wistrom and Villeponteau 1990). Thus, activation of the MAPK cascade is sufficient to promote premature senescence.

\section{MEK activation is required for premature senescence}

To determine whether MEK activity was required for senescence, we took advantage of PD 98059, a highly spe- 
cific noncompetitive MEK inhibitor that prevents its activation by Raf (Alessi et al. 1995; Dudley et al. 1995). IMR90 cells were infected with control or oncogenic Ras-expressing retroviruses, and treated daily with $50 \mu \mathrm{m}$ PD98059 prior to the onset of cell-cycle arrest and the appearance of senescence-rel ated markers ( 3 days postinfection). Notably, this drug concentration has been found previously to be compatible with the proliferation of fibroblasts al beit at slower rates (Pumiglia and Decker 1997). All cultures were monitored for proliferation and senescence as described above.

Remarkably, PD 98059 prevented the onset of Ras-induced arrest but had no effect on the accumulation of vector-containing cells (Fig. 6A). Although the accumuIation rate of Ras-expressing cells treated with PD98059 did not achieve that of untreated cells harboring an empty vector, they displayed an approximately sixfold increase in BrdU incorporation compared to Ras-expressing cells treated with solvent alone (Fig. 6B). Similarly, treatment with PD98059 prevented the appearance of the senescence-like morphology and the upregulation of SA- $\beta$-galactosidase in Ras-expressing cells (Fig. 6C). Moreover, PD98059 had no effect on the detection of SA- $\beta$-gal activity in late passage (senescent) cells, demonstrating that PD98059 does not directly inhibit this enzyme. Thus, these data imply that MEK-and hence the MAPK cascade-is required for premature senescence induced by oncogenic Ras.

MEK arrests primary murine fibroblasts

but transforms fibroblasts lacking p53 or p16 1NK4a

Premature senescence may act as a fail-safe mechanism that suppresses transformation by Ras (Serrano et al. 1997). Thus, whereas oncogenic Ras arrests primary rodent fi broblasts, it readily transforms primary fibrobl asts lacking p53 or INK4a (Tanaka et al. 1994; Serrano et al.
1996). Because MEK is both necessary and sufficient for Ras-induced senescence in human fibroblasts, we asked whether inactivation of p53 or INK4a would overcome MEK-induced arrest in primary rodent cells. Therefore, wild-type, p53-null, and INK4a-null primary mouse embryo fibroblasts (MEFs) were infected with control vector-, Ras-, and $\mathrm{MEK1}^{\mathrm{Q} 56 \mathrm{P}}$-expressing retroviruses, and the rate of cell accumulation was examined in the resulting populations. Of note, our INK4a-null cells have deletions in INK4a exon 2 that may also inactivate p19ARF (Haber 1997, see discussion); hence, these cells are referred to as INK4a $\mathrm{e}^{\mathrm{e} 2-1-}$ for clarity.

As in human fibroblasts, MEK promoted cell-cycle arrest in wild-type MEFs (Fig. 7A). However, unlike in human cells, MEK-arrested MEFs acquired the enlarged and flat senescent morphology characteristic of Ras-expressing MEFs (data not shown). Remarkably, when MEK $1^{\text {Q56P }}$ was expressed at comparable levels in primary $\mathrm{p53}^{-1-}$ and INK4a $\mathrm{ex}^{\mathrm{e}-1-}$ MEFs (Fig. 7B), the resulting populations grew at rates similar to parallel cultures expressing oncogenic Ras, with no indi cation of a growth

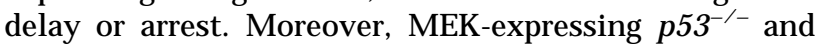
INK4a $\mathrm{e}^{\mathrm{ex}-1-}$ MEFs appeared transformed morphologically (data not shown) and continued to proliferate in low serum (Fig. 7C). Therefore, del etion of either p53 or INK4a ${ }^{e x 2}$ was sufficient to alter the cellular response to MEK from permanent arrest to uncontrolled mitogenesis.

The transformation properties of virus-infected populations were assessed by their ability to grow in suspension and form tumors in immunocompromised mice. In soft-agar assays, MEK-expressing populations grown minimally in culture derived from $\mathrm{p53}^{-1-}$ and

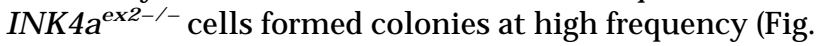
7D). Similarly, MEK-expressing populations derived

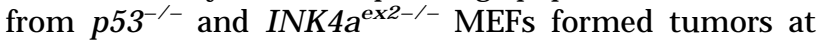
high frequency when injected subcutaneously into athymic nude mice (Table 1). Importantly, the transforma-
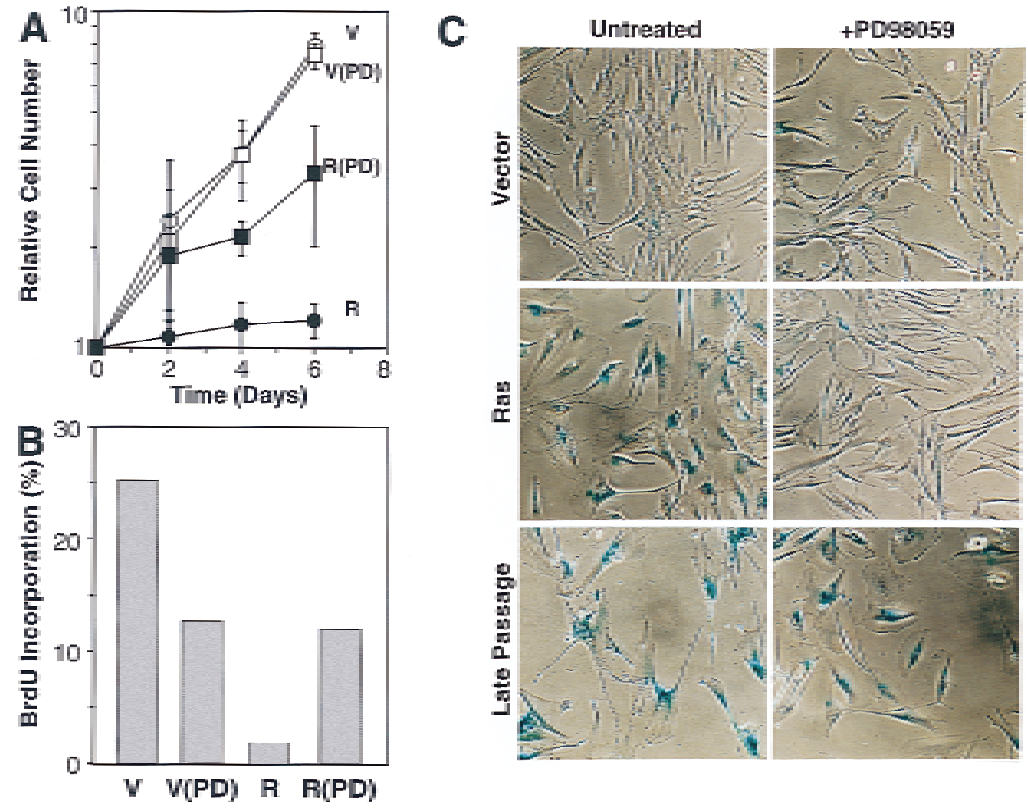

Figure 6. MEK is required for Ras-induced cellcycle arrest and premature senescence. (A) Representative growth curves documenting the effects of PD 98059 on Ras-induced growth arrest. IM R90 cells were infected with an empty vector- or an $\mathrm{H}$-RasV12-expressing retrovirus. Immediately after selection, cell populations were treated daily with medium containing $50 \mu \mathrm{m}$ PD98059 or $0.25 \%$ DM SO (carrier). Each value was determined in triplicate and normalized to the cell number at day 0. (B) Cell populations containing an empty vector (V) or expressing H-RasV12 (R) were treated daily with PD 98059 (PD). On day 6 postselection, cells were pulsed with BrdU and analyzed for BrdU incorporation by flow cytometry. The calculated percentage of BrdU-positive cells is shown. (C) Photomicrographs of control and PD98059-treated cell populations stained for SA- $\beta$-gal activity on day 6 postselection. The percentage of positive cells in each population was 9\% (vector); $12.5 \% \quad$ (vector +PD98059); $80 \% \quad$ (Ras); $15.4 \%$ (Ras +PD98059); 90\% (late passage); $91 \%$ (late passage +PD 98059). 


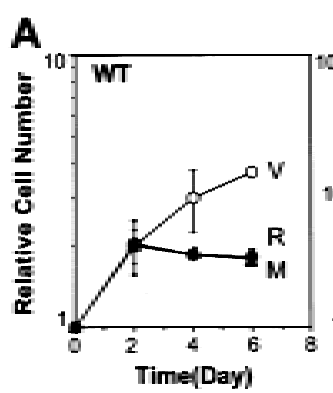

B

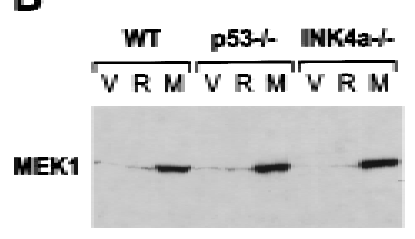

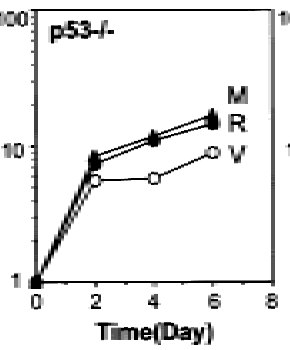
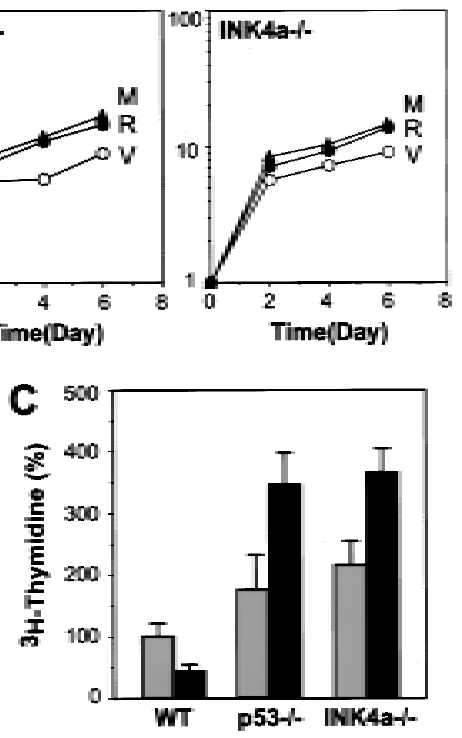

D
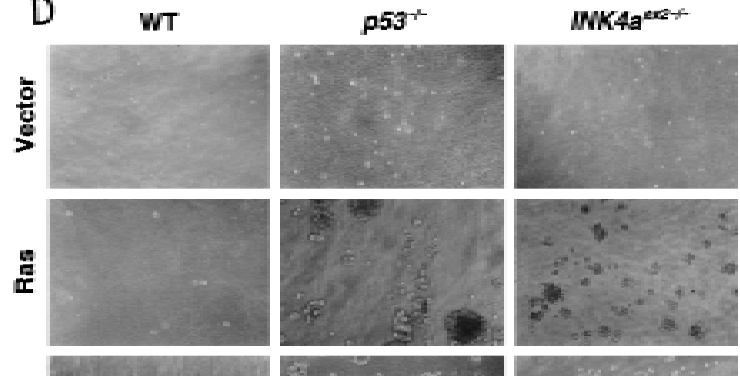

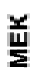
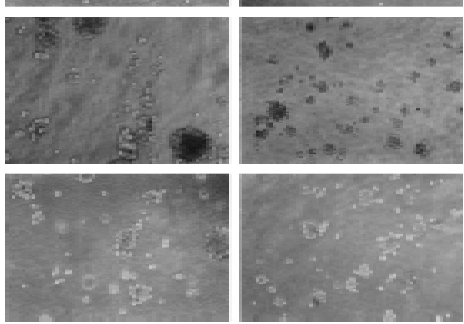

Figure 7. Inactivation of either p53 or INK4a $a^{\mathrm{ex} 2}$ reveals the mitogenic and transforming activity of activated MEK. (A) Representative growth curves corresponding to wildtype (WT), p53-null (p53-1 ) or p16-null (INK4a ex2-1 ) MEFs transduced with empty vector (V), H-RasV12 (R), or $M \operatorname{ME} 1^{\mathrm{Q} 56 \mathrm{P}}(\mathrm{M})$ expressing retroviruses. Each value was determined in triplicate and normal ized to the cell number at day 0 . (B) MEK1 expression in the indicated cell populations was determined by immunoblotting on day 4 postselection. (C) $\left[{ }^{3} \mathrm{H}\right]$ thymidine incorporation in the indicated cell populations containing empty vector (gray bars) or MEK $1^{\mathrm{Q} 56 \mathrm{P}}$ (black bars). On day 6 postselection, cells were transferred to $0.5 \%$ FBS-containing medium for $36 \mathrm{hr}$, followed by a 24-hr pulse with [ $\left.{ }^{3} \mathrm{H}\right]$ thymidine. Each value was determined in triplicate and normalized to the value obtained for wild-type cells containing the empty vector. (D) A nal ysis of anchorage-independent growth of the indicated M EF populations. Immediately following sel ection for virus-transduced populations, $\sim 2 \times 1^{4}$ cells were plated in soft agar (see $M$ aterials and M ethods). Photomicrographs were taken 3 weeks after plating.

tion properties of MEK-expressing cells required cooperation between MEK and loss of either p53 (see also Fukasawa and Vande Woude 1997) or INK4a ${ }^{\text {ex2 }}$, because p53 ${ }^{-1-}$ and INK4a ${ }^{\text {ex2 }-1-}$ M EFs harboring an inert vector neither grew in soft agar nor formed tumors in nude mice. However, MEK1 $1^{\mathrm{Q} 56 \mathrm{P}}$ was not as potent as oncogenic Ras in transforming $\mathrm{p}^{-1-}$ and IN K4a $\mathrm{a}^{\mathrm{ex} 2-1-}$ MEFs, because both soft-agar colonies and tumors expressing MEK were typically smaller than those expressing oncogenic Ras (Fig. 7D; Table 1). The inability of activated MEK to recapitulate the potency of oncogenic Ras in transformation assays is consistent with previous studies showing that multiple effector pathways contribute to Ras-mediated transformation (White et al. 1995).

Table 1. Tumorigenicity assays

\begin{tabular}{|c|c|c|}
\hline MEF genotype ${ }^{a}$ & $\begin{array}{c}\text { Tumor } \\
\text { frequency }\end{array}$ & $\begin{array}{c}\text { Tumor } \\
\text { volume }\left(\mathrm{cm}^{3}\right)\end{array}$ \\
\hline WT (V) & $0 / 4$ & N.A. \\
\hline WT (R) & $0 / 10$ & N.A. \\
\hline WT (M) & $0 / 4$ & N.A. \\
\hline $\mathrm{p} 53^{-1-}(\mathrm{V})$ & $0 / 8$ & N.A. \\
\hline $\mathrm{p} 53^{-1-}(\mathrm{R})$ & $8 / 8$ & $1.40 \pm 0.66$ \\
\hline $\mathrm{p} 53^{-1-}(\mathrm{M})$ & $7 / 8$ & $0.11 \pm 0.087$ \\
\hline INK4a ${ }^{e \times 2-1-}(\mathrm{V})$ & $0 / 8$ & N.A. \\
\hline INK4a ${ }^{e \times 2-1-}(\mathrm{R})$ & $8 / 8$ & $1.34 \pm 1.29$ \\
\hline INK4a ${ }^{e \times 2-1-}(\mathrm{M})$ & $7 / 8$ & $0.21 \pm 0.11$ \\
\hline
\end{tabular}

aprimary MEFs were isolated from wild-type (WT), p53-deficient $\left(\mathrm{p5}^{-1}\right)$, and p16-deficient (INK4a $\left.\mathrm{a}^{\mathrm{e} 2-1}\right)$ mice and infected with control vector $(\mathrm{V}), \mathrm{H}-\mathrm{RasV} 12(\mathrm{R})$, or MEK1 ${ }^{\mathrm{Q} 56 \mathrm{P}}(\mathrm{M})$. ${ }^{\mathrm{b}} \mathrm{N}$ umber of tumors arising per number of sites injected. 'T umor volume measured at 2 weeks $\left[\mathrm{V}=\left(\mathrm{L} \times \mathrm{W}^{2}\right) / 2\right]$.
These data demonstrate that activated MEK efficiently transforms primary MEFs lacking p53 or INK4a ${ }^{\text {ex2 }}$, cells otherwi se predi sposed to immortal ization. Because these MEK-expressing cell populations were derived from primary fibroblasts grown minimally in culture, it seems highly unlikely that additional factors contribute to the transformed phenotype of these cells. Similarly, we show that human fibroblasts expressing an immortalizing oncogene (i.e., E1A) overcome MEK-induced arrest. Together, these data demonstrate that constitutive activation of the MEK/MAPK cascade can produce either premature senescence or forced mitogenesis depending on the integrity of a senescence program controlled by p53 and p16. The precisely opposite response of primary and immortal cells to MEK activation implies that pre mature senescence is a cellular fail-safe mechanism that suppresses the transforming potential of aberrant Ras mitogenic signaling.

\section{Discussion}

Oncogenic Ras transforms immortal rodent fibroblasts, in part, by constitutively transmitting mitogenic signals through the MAPK cascade. By marked contrast, oncogenic Ras acutely activates senescence in primary fibroblasts through the p53 and p16 tumor suppressors (Serrano et al. 1997). Here we demonstrate that Ras signals premature senescence through activation of the MAPK cascade. In normal diploid human fibroblasts, Ras effector loop mutants that retain their ability to bind Raf-1 promoted premature senescence and, among a series of Ras downstream components examined, only activated MEK was capable of inducing p53, p16, and features of 
senescence. Moreover, a MEK inhibitor prevented Rasinduced cell-cycle arrest and senescence. In primary murine fi broblasts, activated MEK arrested wild-type MEFs but forced uncontrolled mitogenesis and transformation

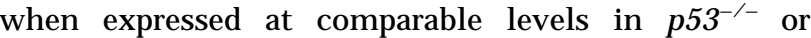
INK4a ex2-1-MEFs. Thus, oncogenic Ras arrests normal cells through the primary mechanism whereby it transforms immortal cells or primary fibroblasts defective in p53 or p16 function.

\section{Role of the MAPK cascade in cell-cycle arrest}

Signaling through the MAPK cascade is relevant to several physiological processes, including mitogenesis, differentiation, and even apoptosis, depending on the celIular context (for review, see Marshall 1998). In some settings, the difference between proliferation and arrest is related to the intensity or duration of the signal (Sewing et al. 1997; Woods et al. 1997; Kerkhoff and Rapp 1998). We show that oncogenic Ras initially forces uncontrolled proliferation, and only later do cells arrest. Importantly, the cell-cycle arrest induced by expression of Ras or MEK is abolished in cells expressing E1A (IM R90), or lacking p53 or p16 (M EFs). In contrast to our observations, others have found that high levels of Raf activity can produce an immediate cell-cycle arrest that occurs independently of p53 or p16 (Sewing et al. 1997; Woods et al. 1997). Perhaps the difference between these studies and ours reflects the fact that other Ras effector pathways can attenuate Raf-induced arrest and impinge upon its ability to activate components of the arrest machinery (Olson et al . 1998); alternatively, they may arise from different levels and kinetics of activation of the Raf/M APK cascade. N evertheless, the results presented here demonstrate clearly that Ras-medi ated MAPK activation can produce two precisely opposite outcomescell-cycle arrest or forced mitogenesis-depending on the integrity of the senescence program controlled by p53 and p16.

Other mitogenic oncogenes can display antiproliferative potential. For example, the c-myc and E1A oncogenes induce proliferation, but both activate p53 to promote apoptosis (for review, see Weinberg 1997). The M yc functions involved in both proliferation and apoptosis are related (Evan et al. 1992; A mati et al. 1993) and, at least in primary cells, the E1A domains required for $\mathrm{p} 53$ accumulation, apoptosis, and oncogenic transformation are inseparable (Samuelson and Lowe 1997). The fact that oncogenic Ras uses the same signal-transduction pathway to promote both arrest and forced mitogenesis reinforces the view that normal cells counter malignant transformation by actively responding to hyperproliferative signals; in this case, by sensing excessive MEK/ MAPK activity and activating senescence. The necessity to overcome these fail-safe mechanisms can explain the phenomenon of oncogene cooperation and may be important during multistep carcinogenesis.

\section{The MAPK cascade and senescence}

The cell-cycle arrest induced by deregulated MEK activ- ity in primary fibroblasts reflects bona fide cellular senescence and not an unusual form of quiescence or differentiation. First, unlike quiescence, both oncogenic Ras and MEK arrest cells at subconfluent densities in the presence of mitogenic growth factors. This arrest is permanent: whereas the MEK inhibitor PD98059 prevents Ras-induced arrest when added prior to the appearance of senescence markers, it cannot reverse the arrest at later times (data not shown). Second, al though p53 and p16 play fundamental roles in Ras-induced arrest, neither have essential roles in differentiation. Indeed, most p53and INK4a ${ }^{\mathrm{ex}}$-deficient mice develop normally (Donehower et al. 1992; Serrano et al. 1996). Cell-cycle arrest induced by Ras and MEK is accompanied by accumulation of p53, p21, p16, and SA- $\beta$-gal activity. Importantly, these markers together are associated with cellular senescence in both fibroblasts and epithelial cells but rarely, if ever, with quiescence or differentiation (A tadja et al. 1995; Dimri et al. 1995; Palmero et al. 1997). Finally, cDN A array analysis of ras-arrested fibroblasts reveals global changes in gene expression consistent with that reported for senescent cells (G. Ferbeyre and S.W. Lowe, unpubl.).

The characterization of Ras-induced arrest in primary fibroblasts as cellular senescence, and the involvement of the MEK/MAPK cascade in this process, have important implications for our understanding of senescence bi ology. Senescence was defined originally by the observation that primary cells have a genetically determined limit to their proliferative potential in cell culture, after which they arrest permanently with characteristic features (Hayflick 1965). Owing to the 'end-replication problem', telomeres shorten during each cell division unless tel omerase is expressed, and it has been proposed that some aspect of excessive tel omere shortening activates cell-cycle arrest and other characteristics of senescence (for review, see Greider 1998). However, a number of exogenous stimuli can also produce a phenotype suggestive of senescence, including DNA damage, DNA-demethylating drugs, ceramide, or inhibitors of histone deacetylation (Holliday 1986; Venable et al . 1995; Ogryzko et al. 1996; Linke et al. 1997), raising the possibility that telomere shortening is not the only signal capable of activating the senescence program.

Our data demonstrate that senescence can be activated in response to deregulated MAPK activation through MEK. Consistent with these results, forced Raf-1 expression also activates senescence in normal human fibroblasts (see Fig. 2B; Zhu et al. 1998). Whereas it remains possible that telomere shortening or some other celldoubling-sensitive mechanism activates senescence through Ras/MAPK signaling, our hypothesis is that senescence can be activated by diverse stimuli leading to engagement of a common cell-cycle arrest program. In this view, the process of senescence is related conceptually to apoptosis, a genetically controlled program carried out by a common cell-death machinery. Diverse stimuli and signaling pathways feed into this machinery, allowing regulation of cell death to be highly versatile. Although less understood, the possibility that multiple 
signaling pathways induce senescence is consistent with cell fusion studies (for review, see Vojta and Barrett 1995). Consequently, the biological roles of cellular senescence may go well beyond the control of cellular or organismal aging, acting as a gl obal anti-proliferative response to a variety of cellular stresses.

\section{The role of p16 and p53 in premature senescence}

The precise role of p16 in tumor suppression is confounded by the complexity of the INK4a locus, which encodes a second tumor suppressor translated in an alternative reading frame designated $\mathrm{p} 19^{\mathrm{ARF}}$ (Quelle et al. 1995). M utations at the INK4a locus often disrupt both p16 and p19ARF (for review, see Haber 1997) and mice lacking p19ARF develop tumors (Kamijo et al. 1997). p19ARF also promotes cell-cycle arrest and primary cells derived from ARF-deficient mice can be transformed by oncogenic Ras al one (Kamijo et al. 1997). Because the

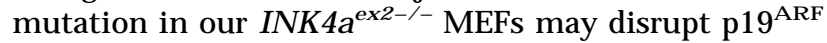
function, it is possible that $\mathrm{p} 19^{\mathrm{ARF}}$ is the sole product of the INK4a/ARF locus responsible for senescence in response to oncogenic Ras. Oncogenes can signal p53 through p19ARF (Zindy et al. 1998; de Stanchina et al. 1998); moreover, oncogenic Ras and MEK induce ARF message and protein and ARF-null MEFs are defective in Ras-induced arrest (Palmero et al. 1998; G. Ferbeyre, A.W. Lin, F. Zindy, M. Roussel, C.J. Sherr, and S.W. Lowe, unpubl.). N evertheless, p16 contributes to Rasinduced senescence. For example, p16 accumulates in response to oncogenic Ras and MEK, and expression of a p16-insensitive Cdk4 mutant (R24C) (Wolfel et al. 1995) counters Ras-induced growth arrest (Serrano et al. 1997). Furthermore, in human cells, p16 can directly induce senescence (U hrbom et al. 1997; M cC onnell et al. 1998) and can be inactivated spontaneously during the immortalization process (Reznikoff et al. 1996; Foster et al. 1998). Regardless of the relative contribution of p16 and p19ARF to this process, the INK4a ${ }^{\text {ex2 }}$-deficient cells used accurately recapitulate mutations in human tumors.

In rodent cells, the cell-cycle arrest induced by activated MEK is abrogated by inactivation of either p53 or p16 (Fig. 7; see al so Serrano et al. 1997). Nevertheless, p53 and p16 do not function in a simple linear pathway. p16 levels increase in response to Ras in p53 $3^{-1-}$ MEFs and, conversely, p53 levels increase in INK4a ${ }^{e \times 2-1-M E F s}$ (data not shown). Introduction of oncogenic Ras or MEK

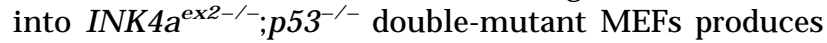
more transformed foci than in either single mutant (A.W. Lin and S.W. Lowe, unpubl.). Thus, p53 and p16 (and perhaps p19ARF) act cooperatively to promote Rasinduced arrest, and disruption of either p53 or p16 prevents arrest and is sufficient for transformation. In human cells, p53 and p16 also appear to cooperate to promote arrest, although inactivation of both pathways appears necessary to escape senescence (see di scussion in Serrano et al. 1997). Consistent with this view, ectopic expression of p21 (a p53 target) and p16 can induce senescence in human cells (M cConnell et al . 1998; Vogt et al. 1998).
The activation of p53 and p16 in response to deregulated MEK/MAPK signaling provides a rel evant setting in which these tumor suppressors act to limit malignant transformation. In this view, mutations that deregulate the MAPK cascade provide an initial proliferative advantage but also accelerate senescence. However, cells acquiring mutations in p53 or at the INK4a/ARF locus escape senescence, thereby revealing the full mitogenic potential of the MAPK cascade. Consistent with this scenario, ras mutations often precede mutations in p53 or INK4a during tumor development (Fearon and Vogelstein 1990; Burns et al. 1991; Linardopoulos et al. 1995).

\section{Premature senescence and tumor suppression}

In summary, our data demonstrate that oncogenic Ras promotes premature senescence through activation of the MAPK cascade. Remarkably, this is the same pathway whereby Ras induces mitogenesis in immortal cells. Escape from Ras-induced senescence al lows inappropriate proliferation and, in rodent cells, oncogenic transformation. Consequently, the biological outcome of constitutive MAPK activation-cell-cycle arrest or forced mitogenesis-is largely context-dependent and determined by the integrity of the senescence machinery. These data strongly support the notion that normal cells possess fail-safe mechanisms that limit the consequences of Ras mitogenic signaling. Because these safeguards involve p53 and p16, the activation of premature senescence in response to forced mitogenic signaling may be an important mechanism of tumor suppression.

\section{Materials and methods}

\section{Cell culture}

N ormal diploid human IM R90 fibroblasts (early-mid passages) expressed the murine ecotropic receptor (Serrano et al. 1997), and primary mouse embryo fibroblasts derived from wild-type, p53 $3^{-1-}$ and INK4a ${ }^{e \times 2-1-}$ day 13.5 embryos were prepared as described previously (Jacks et al. 1994; Serrano et al. 1997). All cultures were maintained in Dulbecco's modified Eagle medium (DMEM; GIBCO) supplemented with $10 \%$ fetal bovine serum (FBS; Sigma) and 1\% penicillin G/streptomycin sulfate (Sigma).

\section{Retroviral vectors and gene transfer}

Oncogenic Ras (H-RasV12) (Serrano et al. 1997) and Ras effector loop mutants (White et al. 1995; Joneson et al. 1996) were expressed using the pBabe-Puro vector (M orgenstern and Land 1990). CDNA encoding Racl (N 115I), RalA, RhoA (Q63L), RRas (G38V), TC21 (Q72L), PI(3)Kp110 $\alpha$ (K227E), PI(3)Kp110 $\alpha-$ CAAX, wild-type Akt, or E1A12S, respectively, were cloned into a pLPC retroviral vector. Raf-1-CAAX was cloned into a Babe-Puro retroviral vector. M EK1 ${ }^{\text {Q56P }}$ (Bottorff et al. 1995) was expressed using Babe-Puro- or WZL-H ygro-based retroviral vectors (Ariad Pharmaceuticals, unpubl.). Retroviral gene transfer was performed as described (Serrano et al. 1997) using high-titer retroviral stocks generated by transient transfection of the Phoenix ecotropic packaging line (G. N olan, Stanford University, CA). Infected cell populations were selected by culture in puromycin $(2.5 \mu \mathrm{g} / \mathrm{ml}, 3$ days $)$ or in hygromycin $(200 \mu \mathrm{g} / \mathrm{ml}, 5$ days) to eliminate uninfected cells. Day 4 postinfection was 
desi gnated as day 0 (Serrano et al. 1997). In all experiments, cells infected with an empty vector were used as control.

\section{Analysis of cell proliferation}

Cell proliferation was assessed by three criteria: growth curves, $\left[{ }^{3} \mathrm{H}\right]$ thymidine incorporation and flow cytometry of BrdU-labeled cells. For growth curves, cells were plated at a density of $2.5 \times 10^{4}$ per well in 12-well-plates following drug selection. Cells were fixed in $10 \%$ formal in at the indicated times according to a time scheme and method described previously (Serrano et al. 1997). Crystal violet (0.1\%; Sigma) was used to stain cells. Cell-associated dye was extracted in $2 \mathrm{ml}$ of $10 \%$ acetic acid and the optical density was measured at $590 \mathrm{~nm}$ with each value normalized to day 0 . Each point was done in triplicate, each growth curve was performed at least twice. For experiments using PD 98059 (Calbiochem), treatment was initiated 2 days postinfection. Cells were fed daily with fresh medium containing $50 \mu \mathrm{M}$ PD 98059 containing 0.25\% DM SO. Solvent-containing medium was used to treat control cultures in parallel.

For $\left[{ }^{3} \mathrm{H}\right]$ thymidine incorporation assay, $2 \times 10^{4}$ cells per well in 12-well-plates were plated in triplicate. Cells were pulsed for 20-24 hr or $4 \mathrm{hr}$ with $5 \mu \mathrm{Ci} / \mathrm{ml}$ [methyl- ${ }^{3} \mathrm{H}$ ]thymidine (Amersham, $2 \mathrm{Ci} / \mathrm{mmoles}$ ). After washing with PBS, cells were trypsinized and transferred to glass fiber filters (Filtermat, Wallac) followed by scintillation counting. For BrdU incorporation and DNA-content analysis, subconfluent cultures were label ed with $10 \mu \mathrm{M}$ BrdU (Amersham) for $4 \mathrm{hr}$. Cells were trypsinized and fixed in $75 \%$ ethanol for $30 \mathrm{~min}$. Cells were washed in PBS and were treated subsequently with $2 \mathrm{M} \mathrm{HCl}$ for $20 \mathrm{~min}$ at room temperature. After washing in washing buffer (0.1\% BSA/PBS), cells were neutral ized in $0.1 \mathrm{~m}$ sodium borate for $2 \mathrm{~min}$ followed by washing in washing buffer. Cells were incubated subsequently with FITC-conjugated anti-BrdU antibody (Pharmingen) for $1 \mathrm{hr}$ at room temperature or overnight at $4^{\circ} \mathrm{C}$. Finally, cells were washed in washing buffer three times followed by treatment with propidium iodide $(10 \mu \mathrm{g} / \mathrm{ml})$ and RN ase A (100 $\mu \mathrm{g} / \mathrm{ml}$ ) at $37^{\circ} \mathrm{C}$ for $30 \mathrm{~min}$. Samples were analyzed by two-dimensional flow cytometry to detect both fluorescein and propidium iodide.

\section{Protein expression and activity}

Western blot analysis was carried out as described previously with minor modifications (Serrano et al. 1997). Whole-cell lysates were derived by lysing cell pel lets in Laemmli SDS sample buffer. Samples corresponding to $30 \mu \mathrm{g}$ of protein were resolved on SDS-PAGE gels and transferred to immobilone-P membranes (Millipore). The following antibodies were used: CM 1 (N ovocastra) at 1:1000 dilution for the detection of p53, antiWAF1(p21) antibody (C-19; Santa Cruz) at 1:500 dilution, antip16 antibody (DCS-50; N ovocastra) at 1:200 dilution, anti-Rb (G3-245; Pharmingen) at $0.5 \mu \mathrm{g} / \mathrm{ml}$ together with $\mathrm{C}-36$ and $\mathrm{XZ}$ 55 hybridoma supernatant at 1:100 dilution each. Anti-cyclin A (Santa Cruz) at 1:500 di lution. Anti-Ras antibody (Santa Cruz) at 1:500 dilution. Western bl ot analysis was accomplished according to standard procedures using ECL detection (Amersham).

For MAPK assays, cells were lysed in lysis buffer $(20 \mathrm{~mm}$ Tris- $\mathrm{HCl}$ at $\mathrm{pH}$ 7.5, $150 \mathrm{~mm} \mathrm{NaCl}, 1 \mathrm{~mm}$ EDTA, $1 \mathrm{~mm}$ EGTA, $1 \%$ Triton $X-100,2.5 \mathrm{~mm}$ sodium pyrophosphate, $1 \mathrm{~mm} \beta$-glycerol phosphate, $1 \mathrm{~mm} \mathrm{Na}_{3} \mathrm{VO}_{4}, 1 \mu \mathrm{g} / \mathrm{ml}$ leupeptin, $1 \mathrm{~mm}$ PMSF) accompanied by brief sonication on ice. Protein lysate $(100 \mu \mathrm{g})$ was incubated with a polyclonal antibody against ERK2 (1:50 dilution; Santa Cruz) for $3 \mathrm{hr}$ at $4^{\circ} \mathrm{C}$. Afterwards, $25 \mu$ of protein A-Sepharose beads $(50 \%)$ were added to the mixture and were incubated for another $3 \mathrm{hr}$ at $4^{\circ} \mathrm{C}$. Samples were washed subsequently and resuspended in $20 \mu$ l of kinase buffer ( $25 \mathrm{~mm}$ Tris-
$\mathrm{HCl}$ at $\mathrm{pH} 7.5,10 \mathrm{~mm} \mathrm{M} \mathrm{gCl}, 5 \mathrm{~mm} \beta$-glycerol phosphate, $2 \mathrm{~mm}$ DTT, $0.1 \mathrm{mM} \mathrm{Na}_{3} \mathrm{VO}_{4}$ ) supplemented with $10 \mu \mathrm{Ci}\left[\gamma^{-32} \mathrm{P}\right] \mathrm{ATP}$ (3000 Ci/mmoles) and $5 \mu \mathrm{g}$ of myelin basic protein (MBP; Sigma) and the reaction mixtures were incubated at $30^{\circ} \mathrm{C}$ for 30 min. The samples were resolved on $12 \%$ SDS-polyacrylamide gels and exposed to Kodak X-OMAT AR.

SA- $\beta$-galactosidase activity was detected as described previously (Dimri et al. 1995) with minor modifications. Cells were washed with PBS, fixed in $0.5 \%$ glutaral dehyde, and were incubated with staining solution $[1 \mathrm{mg} / \mathrm{ml}$ 5-bromo-4-chloro-3-indolyl $\beta$-galactoside (X-gal), $5 \mathrm{~mm}$ potassium ferrocyanide, $5 \mathrm{~mm}$ potassium ferricyanide, $1 \mathrm{~mm} \mathrm{M} \mathrm{MCl}_{2}$ in PBS at $\mathrm{pH}$ 6.0] for $\sim 12 \mathrm{hr}$ at $37^{\circ} \mathrm{C}$.

\section{Transformation assays}

For soft-agar assays, cells were resuspended in $0.3 \% \mathrm{~N}$ oble agar (in DMEM supplemented with $10 \%$ FBS) at a density of $2 \times 10^{4}$ cells per well (in six-well plates), and were plated onto solidifed $0.5 \% \mathrm{~N}$ oble agar-containing bottom layer medium. Cultures were fed weekly and photomicrographs of colonies were taken 3 weeks postplating. Experiments were repeated twice, and M EFs from two different embryo preparations were used in each assay.

For in vivo tumorigenicity assays, $10^{6}$ cells $/ 0.25 \mathrm{ml}$ of PBS were injected subcutaneously into male NSW athymic nude mice (T atonic Farms). Each animal received two injections, one on each rear flank. Virus-infected MEFs from two different embryo preparations were used for each genotype, and at least two animals were examined for each cell population (i.e., four tumors). Tumor formation was monitored three times per week by pal pation at the sites of injection. The length $(L)$ and width (W) of tumors were measured using a caliper and the volume of tumor formed was determined using the formula $\mathrm{V}=\left(\mathrm{L} \times \mathrm{W}^{2}\right) / 2$.

\section{Acknowledgments}

We are very grateful to G. Clark, P. Rodriguez-Viciana, J. Downward, and $\mathrm{I}$. M érida for generously providing reagents and to $M$. McMahon for discussing unpublished work. We thank $D$. Beach, B. Stillman, W. Herr, and G. Hannon for support and advice, and the Cold Spring Harbor Laboratory Flow Cytometry Facility and Graphic Arts Department for their patience and help. We also thank our colleagues for helpful comments and criticisms. S.W.L. and L.V.A. are Kimmel Scholars, M.S. is supported by grant PM 95-0014 from Direccion general de investigacion y tecnica, Spain, and by a core grant from Pharmacia and Upjohn and from the Spanish Research Council, L.V.A. and S.W.L. are supported by grants CA 72982 and CA 13106, respectively, from the $\mathrm{N}$ ational Cancer Institute.

The publication costs of this article were defrayed in part by payment of page charges. This article must therefore be hereby marked 'advertisement' in accordance with 18 USC section 1734 solely to indicate this fact.

\section{References}

Alcorta, D.A., Y. Xiong, D. Phelps, G. Hannon, D. Beach, and J.C. Barrett. 1996. Involvement of the cyclin-dependent kinase inhibitor p16 (INK4a) in replicative senescence of normal human fibroblasts. Proc. Natl. Acad. Sci. 93: 13742-13747.

Alessi, D.R., A. Cuenda, P. Cohen, D.T. Dudley, and A.R. Saltiel. 1995. PD 098059 is a specific inhibitor of the activation of mitogen-activated protein kinase kinase in vitro and in vivo. J. Biol. Chem. 270: 27489-27494. 
Amati, B., M.W. Brooks, N. Levy, T.D. Littlewood, G.I. Evan, and $\mathrm{H}$. Land. 1993. Oncogenic activity of the c-M yc protein requires dimerization with $\mathrm{M}$ ax. Cell 72: 233-245.

Atadja, P., H. Wong, I. Garkavtsev, C. Veillette, and K. Riabowol. 1995. Increased activity of p53 in senescing fibroblasts. Proc. Natl. Acad. Sci. 92: 8348-8352.

Bottorff, D., S. Stang, S. Agellon, and J.C. Stone. 1995. RAS signalling is abnormal in a c-raf1 M EK1 double mutant. Mol. Cell. Biol. 15: 5113-5122.

Burns, P.A., C.J. Kemp, J.V. Gannon, D.P. Lane, R. Bremner, and A. Balmain. 1991. Loss of heterozygosity and mutational alterations of the p53 gene in skin tumours of interspecific hybrid mice. Oncogene 6: 2363-2369.

Chen, R.H., C. Sarnecki, and J. Blenis. 1992. N uclear localization and regulation of erk- and rsk-encoded protein kinases. Mol. Cell. Biol. 12: 915-927.

Chin, L., J. Pomerantz, D. Polsky, M. Jacobson, C. Cohen, C. Cordon-Cardo, J.W.N. Horner, and R.A. DePinho. 1997. Cooperative effects of INK4a and ras in melanoma susceptibility in vivo. Genes \& Dev. 11: 2822-2834.

Cowley, S., H. Paterson, P. Kemp, and C.J. Marshall. 1994. Activation of MAP kinase kinase is necessary and sufficient for PC12 differentiation and for transformation of $\mathrm{NIH}$ 3T3 cells. Cell 77: 841-852.

de Stanchina, E., M.E. McCurrach, F. Zindy, S. Shieh, G. Ferbeyre, A.V. Samuelson, C. Prives, M.F. Roussel, C.J. Sherr, and S.W. Lowe. 1998. E1A signaling to p53 involves the p19ARF tumor suppressor. Genes \& Dev. 12: 2434-2442.

Dimri, G.P., X. Lee, G. Basile, M. A costa, G. Scott, C. Roskelley, E.E. M edrano, M. Linskens, I. Rubelj, O. Pereira-Smith, et al 1995. A biomarker that identifies senescent human cells in culture and in aging skin in vivo. Proc. Natl. Acad. Sci. 92: 9363-9367.

Donehower, L.A., M. Harvey, B.L. Slagle, M.J. McArthur, C.A. M ontgomery, Jr., J.S. Butel, and A. Bradley. 1992. Mice deficient for p53 are devel opmentally normal but susceptible to spontaneous tumours. Nature 356: 215-221.

Downward, J. 1998. Ras signalling and apoptosis. Curr. Opin. Genet. Dev. 8: 49-54.

Dudley, D.T., L. Pang, S.J. Decker, A.J. Bridges, and A.R. Saltiel. 1995. A synthetic inhibitor of the mitogen-activated protein kinase cascade. Proc. Natl. Acad. Sci. 92: 7686-7689.

Evan, G.I., A.H. Wyllie, C.S. Gilbert, T.D. Littlewood, H. Land, M. Brooks, C.M. Waters, L.Z. Penn, and D.C. Hancock. 1992. Induction of apoptosis in fibroblasts by c-myc protein. Cell 69: 119-128.

Fearon, E.R. and B. Vogelstein. 1990. A genetic model for colorectal tumorigenesis. Cell 61: 759-767.

Foster, S.A., D.J. Wong, M.T. Barrett, and D.A. Galloway. 1998. Inactivation of p16 in human mammary epithelial cells by CpG island methylation. Mol. Cell. Biol. 18: 1793-1801.

Franza, B.R., Jr., K. Maruyama, J.I. Garrels, and H.E. Ruley. 1986. In vitro establishment is not a sufficient prerequisite for transformation by activated ras oncogenes. Cell 44: 409418.

Fukasawa, K. and G.F. Vande Woude. 1997. Synergy between the M os/mitogen-activated protein kinase pathway and loss of p53 function in transformation and chromosome instability. Mol. Cell. Biol. 17: 506-518.

Gallimore, P.H., R.J. Grand, and P.J. Byrd. 1986. Transformation of human embryo retinoblasts with simian virus 40 , adenovirus and ras oncogenes. Anticancer Res. 6: 499-508.

Gille, H., M. Kortenjann, O. Thomae, C. Moomaw, C. Slaughter, M.H. Cobb, and P.E. Shaw. 1995. ERK phosphorylation potentiates Elk-1-mediated ternary complex formation and transactivation. EMBO J. 14: 951-962.
Graeber, T.G., C. Osmanian, T. Jacks, D.E. Housman, C.J. Koch, S.W. Lowe, and A.J. Giaccia. 1996. Hypoxia-mediated selection of cells with diminished apoptotic potential in solid tumours. Nature 379: 88-91.

Graham, S.M ., A.B. Vojtek, S.Y. Huff, A.D. Cox, G.J. Clark, J.A Cooper, and C.J. Der. 1996. TC21 causes transformation by Raf-independent signaling pathways. Mol. Cell. Biol. 16: $6132-6140$.

Greider, C.W. 1998. Tel omeres and senescence: the history, the experiment, the future. Curr. Biol. 8: R178-R181.

Haber, D.A. 1997. Splicing into senescence: the curious case of p16 and p19ARF. Cell 91: 555-558.

Hayflick, L. 1965. The limited in vitro lifetime of human diploid cell strains. Exp. Cell. Res. 37: 614-636.

Hirakawa, T. and H.E. Ruley. 1988. Rescue of cells from ras oncogene-induced growth arrest by a second, complementing, oncogene. Proc. Natl. Acad. Sci. 85: 1519-1523.

Holliday, R. 1986. Strong effects of 5-azacytidine on the in vitro lifespan of human diploid fibroblasts. Exp. Cell. Res. 166: 543-552.

Jacks, T., L. Remington, B.O. Williams, E.M. Schmitt, S. Halachmi, R.T. Bronson, and R.A. Weinberg. 1994. Tumor spectrum analysis in p53-mutant mice. Curr. Biol. 4: 1-7.

Jiang, H., J.Q. Luo, T. U rano, P. Frankel, Z. Lu, D.A. Foster, and L.A. Feig. 1995. Involvement of Ral GTPase in v-Src-induced phospholipase D activation. Nature 378: 409-412.

Joneson, T., M.A. White, M.H. Wigler, and D. Bar-Sagi. 1996. Stimulation of membrane ruffling and MAP kinase activation by distinct effectors of RAS. Science 271: 810-812.

Kamijo, T., F. Zindy, M.F. Roussel, D.E. Quelle, J.R. Downing, R.A. A shmun, G. Grosveld, and C.J. Sherr. 1997. Tumor suppression at the mouse INK4a locus mediated by the al ternative reading frame product p19ARF. Cell 91: 649-659.

Kastan, M.B. 1993. P53: A determinant of the cell cycle response to DN A damage. Adv. Exp. Med. Biol. 339: 291-293.

Katz, M.E. and F. McCormick. 1997. Signal transduction from multiple Ras effectors. Curr. O pin. Genet. Dev. 7: 75-79.

Kemp, C.J., L.A. Donehower, A. Bradley, and A. Balmain. 1993. Reduction of p53 gene dosage does not increase initiation or promotion but enhances malignant progression of chemically induced skin tumors. Cell 74: 813-822.

Kerkhoff, E. and U.R. Rapp. 1998. High-intensity Raf signals convert mitotic cell cycling into cellular growth. Cancer Res. 58: 1636-1640.

Khosravi-Far, R., P.A. Solski, G.J. Clark, M.S. Kinch, and C.J. Der. 1995. Activation of Racl, RhoA, and mitogen-activated protein kinases is required for Ras transformation. Mol. Cell. Biol. 15: 6443-6453.

Linardopoulos, S., A.J. Street, D.E. Quelle, D. Parry, G. Peters, C.J. Sherr, and A. Balmain. 1995. Deletion and altered regulation of p16IN K4a and p15IN K4b in undifferentiated mouse skin tumors. Cancer Res. 55: 5168-5172.

Linke, S.P., K.C. Clarkin, and G.M. Wahl. 1997. p53 mediates permanent arrest over multiple cell cycles in response to gamma-irradiation. Cancer Res. 57: 1171-1179.

Lumpkin, C.K., J.E. Knepper, J.S. Butel, J.R. Smith, and O.M. Pereira-Smith. 1986. Mitogenic effects of the proto-oncogene and oncogene forms of $\mathrm{c}-\mathrm{H}$-ras DN A in human diploid fibroblasts. Mol. Cell. Biol. 6: 2990-2993.

Mansour, S.J., W.T. Matten, A.S. Hermann, J.M. Candia, S. Rong, K. Fukasawa, G.F. Vande Woude, and N.G. A hn. 1994. Transformation of mammalian cells by constitutively active MAP kinase kinase. Science 265: 966-970.

Marshall, C.J. 1994. MAP kinase kinase kinase, MAP kinase kinase and MAP kinase. Curr. O pin. Genet. Dev. 4: 82-89. . 998. Signal transduction. Taking the Rap. Nature 
392: 553-554.

Marte, B.M., P. Rodriguez-Viciana, S. Wennstrom, P.H. Warne, and J. Downward. 1997. R-Ras can activate the phosphoinositide 3-kinase but not the MAP kinase arm of the Ras effector pathways. Curr. Biol. 7: 63-70.

McConnelI, B.B., M. Starborg, S. Brookes, and G. Peters. 1998. Inhibitors of cyclin-dependent kinases induce features of replicative senescence in early passage human diploid fibroblasts. Curr. Biol. 8: 351-354.

Morgenstern, J.P. and H. Land. 1990. Advanced mammalian gene transfer: high titre retroviral vectors with multiple drug selection markers and a complementary hel per-free packaging cell line. Nucleic Acids Res. 18: 3587-3596.

Noda, A., Y. Ning, S.F. Venable, O.M. Pereira-Smith, and J.R. Smith. 1994. Cloning of senescent cell-derived inhibitors of DNA synthesis using an expression screen. Exp. Cell. Res. 211: $90-98$.

Ogryzko, V.V., T.H. Hirai, V.R. Russanova, D.A. Barbie, and B.H. Howard. 1996. Human fibroblast commitment to a senescence-like state in response to histone deacetylase inhibitors is cell cycle dependent. Mol. Cell. Biol. 16: 5210-5218.

Olson, M. F., H. F. Paterson, and C. J Marshall. 1998. Signals from Ras and Rho GTPases interact to regulate expression of p21Waf1/Cip1. Nature 394: 295-299.

Palmero, I., B. McConnell, D. Parry, S. Brookes, E. Hara, S. Bates, P. Jat, and G. Peters. 1997. Accumulation of p16IN K4a in mouse fibroblasts as a function of replicative senescence and not of retinoblastoma gene status. Oncogene 15: 495503.

Palmero, I., C. Pantoja, and M. Serrano. 1998. p19ARF links the tumour-suppressor p53 to ras. Nature 395: 125-126.

Pumiglia, K.M . and S.J. Decker. 1997. Cell cycle arrest mediated by the MEK/mitogen-activated protein kinase pathway. Proc. Natl. Acad. Sci. 94: 448-452.

Quelle, D.E., F. Zindy, R.A. Ashmun, and C.J. Sherr. 1995. Alternative reading frames of the IN K4a tumor suppressor gene encode two unrel ated proteins capable of inducing cell cycle arrest. Cell 83: 993-1000.

Reznikoff, C.A., T.R. Yeager, C.D. Belair, E. Savelieva, J.A. Puthenveettil, and W.M. Stadler. 1996. Elevated p16 at senescence and loss of p16 at immortalization in human papillomavirus 16 E6, but not E7, transformed human uroepithelial cells. Cancer Res. 56: 2886-2890.

Rodriguez-Viciana, P., P.H. Warne, R. Dhand, B. Vanhaesebroeck, I. Gout, M.J. Fry, M.D. Waterfield, and J. Downward. 1994. Phosphatidylinositol-3-OH kinase as a direct target of Ras. Nature 370: 527-532.

Rodriguez-Viciana, P., P.H. Warne, A. Khwaja, B.M. Marte, D. Pappin, P. Das, M.D. Waterfield, A. Ridley, and J. Downward. 1997. Role of phosphoinositide 3-OH kinase in cell transformation and control of the actin cytoskel eton by Ras. Cell 89: 457-467.

Ruley, H.E. 1990. Transforming collaborations between ras and nuclear oncogenes. Cancer Cells 2: 258-268.

Samuelson, A.V. and S.W. Lowe. 1997. Selective induction of p53 and chemosensitivity in RB-deficient cells by E1A mutants unable to bind the RB-related proteins. Proc. Natl. Acad. Sci. 94: 12094-12099.

Serrano, M., H. Lee, L. Chin, C. Cordon-Cardo, D. Beach, and R.A. DePinho. 1996. Role of the IN K4a locus in tumor suppression and cell mortality. Cell 85: 27-37.

Serrano, M., A.W. Lin, M.E. McCurrach, D. Beach, and S.W. Lowe. 1997. Oncogenic ras provokes premature cell senescence associated with accumulation of p53 and p16IN K4a. Cell 88: 593-602.

Sewing, A., B. Wiseman, A.C. Lloyd, and H. Land. 1997. High- intensity Raf signal causes cell cycle arrest mediated by p21Cip1. Mol. Cell. Biol. 17: 5588-5597.

Spaargaren, M. and J.R. Bischoff. 1994. Identification of the guanine nucleotide dissociation stimulator for Ral as a putative effector molecule of R-ras, H-Ras, K-ras, and Rap. Proc. Natl. Acad. Sci. 91: 12609-12613.

Stang, S., D. Bottorff, and J.C. Stone. 1997. Interaction of activated Ras with Raf-1 al one may be sufficient for transformation of rat2 cells. Mol. Cell. Biol. 17: 3047-3055.

Tanaka, N ., M. Ishihara, M. Kitagawa, H. Harada, T. Kimura, T. Matsuyama, M.S. Lamphier, S. Aizawa, T.W. Mak, and T. Taniguchi. 1994. Cellular commitment to oncogene-induced transformation or apoptosis is dependent on the transcription factor IRF-1. Cell 77: 829-839.

U hrbom, L., M. N ister, and B. Westermark. 1997. Induction of senescence in human malignant glioma cells by p16INK4a. Oncogene 15: 505-514.

U rano, T., R. Emkey, and L.A. Feig. 1996. Ral-GTPases mediate a distinct downstream signaling pathway from Ras that facilitates cellular transformation. EMBO J. 15: 810-816.

Van Aelst, L. and C. D'Souza-Schorey. 1997. Rho GTPases and signaling networks. Genes \& Dev. 11: 2295-2322.

Van A elst, L., M. Barr, S. M arcus, A. Polverino, and M. Wigler. 1993. Complex formation between RAS and RAF and other protein kinases. Proc. Natl. Acad. Sci. 90: 6213-6217.

Venable, M.E., J.Y. Lee, M.J. Smyth, A. Bielawska, and L.M. Obeid. 1995. Role of ceramide in cellular senescence. J. Biol. Chem. 270: 30701-30708.

Vogt, M., C. Haggblom, J. Y eargin, T. Christiansen-Weber, and M. Haas. 1998. Independent induction of senescence by p16IN K4a and p21CIP1 in spontaneously immortalized human fibroblasts. Cell Growth Differ. 9: 139-146.

Vojta, P.J. and J.C. Barrett. 1995. Genetic analysis of cellular senescence. Biochim. Biophys. Acta 1242: 29-41.

Weinberg, R.A. 1989. Oncogenes, antioncogenes, and the molecular bases of multistep carcinogenesis. Cancer Res. 49: 3713-3721.

-_- 1997. The cat and mouse games that genes, viruses, and cells play. Cell 88: 573-575.

White, M.A., C. Nicolette, A. Minden, A. Polverino, L. Van Aelst, M. Karin, and M.H. Wigler. 1995. Multiple Ras functions can contribute to mammalian cell transformation. Cell 80: 533-541.

Wistrom, C. and B. Villeponteau. 1990. Long-term growth of diploid human fibroblasts in low serum media. Exp. Gerontol. 25: 97-105.

Wolfel, T., M. Hauer, J. Schneider, M. Serrano, C. Wolfel, E. Klehmann-Hieb, E. De Plaen, T. Hankeln, K.H. Meyer zum Buschenfelde, and D. Beach. 1995. A pl6IN K4a-insensitive CDK4 mutant targeted by cytolytic $T$ lymphocytes in a human melanoma. Science 269: 1281-1284.

Woods, D., D. Parry, H. Cherwinski, E. Bosch, E. Lees, and M. McM ahon. 1997. Raf-induced proliferation or cell cycle arrest is determined by the level of Raf activity with arrest mediated by p21Cipl. Mol. Cell. Biol. 17: 5598-5611.

Zhu, J., D. Woods, M. M cM ahon, and J.M. Bishop. 1998. Senescence of human fibroblasts induced by oncogenic Raf. Genes $\&$ Dev. (this issue).

Zindy, F., Quelle, D.E., Roussel, M.F., and C.J. Sherr. 1997. Expression of the p16INK4a tumor suppressor verses other IN K4 family members during mouse devel opment and aging. Oncogene 15: 203-211.

Zindy, F., C.M . Eischen, D.H. Randle, T. Kamijo, J.L. Cleveland, C.J. Sherr, and M.F. Roussel. 1998. Myc signaling via the ARF tumor suppressor regulates p53-dependent apoptosis and immortalization. Genes \& Dev. 12: 2424-2433. 